\title{
AREK-AREK SUROBOYO: MENANGKAP HIKMAH DARE KONFLIK
}

\author{
01eh:PatBadrun
}

\begin{abstract}
Abstrak
Konflik-konflik sosial bernuansa agama yang terjadi di beberapa daerah termasuk di daerah Jawa Timur, tidak dapat disangkal telah memberikan dampak terhadap kerukunan umat beragama di Kota Surabaya. Namun demikian, dampak yang dipandang menonjol ialah meningkatnya kewaspadaan pihak-pihak terkait yang disusul dengan tindakan nyata sehingga konflik serupa tidak sempat terjadi di Surabaya.

Penelitian ini menemukan bahwa setidaknya ada dua hal yang mendukung terciptanya kondisi tersebut, yakni: (1) tingkat kesadaran yang tinggi dari para pemimpin dan pemuka/tokoh agama dan masyarakat setempat tentang pentingnya menjaga dan memelihara kerukunan umat beragama yang juga berarti kerukunan masyarakat; (2) ciri dan sifat khas orang Surabaya (arek-arek Suroboyo) yakni pragmatis, egaliter, terbuka, lugas, dan kritis.
\end{abstract}

\section{PENDAHULUAN}

Tulisan ini, merupakan bagian tak terpisahkan dari Penelitian Studi Kerukunan Umat Beragama Pasca Konflik di derbagai Daerah yang dilaksanakan Puslitbang Kehidupan Beragama, Badan Litbang Agama, dan Diktat Keagamaan Departemen Agama Tahun 2005. Penelitian lapangan berlangsung di Kota Surabaya pada bulan Juni 2005 selama 8 hari kerja sesuai "kontrak".

Penelitian bertujuan untuk mengetahui dinamika suasana kerukunan umat beragama pasca konflik di daerah/lokasi yang diteliti meliputi aktivitas keagamaan, interaksi sosial, serta peran pemerintah dan masyarakat setempat dalam upaya pemeliharaan kerukunan umat beragama. Selain itu, penelitian 
juga bertujuan untuk mengetahui hal-hal yang dipandang sebagai faktor pendukung dan faktor penghambat pemeliharaan kerukunan umat beragama di lokasi penelitian.

Inforraasi hasil penelitian diharapkan berguna sebagai masukan kebijakan pemerintah berkaitan dengan program peningkatan kerukunan umat beragama yang dinamis dan berwawasan kultural, baik intern maupun antar umat beragama.

Secara metodologis, penelitian ini menggunakan tiga teknik pengumpulan data yaitu: (1) Studi kepustakaan dan literatur untuk menelusuri literatur dan dokumen yang berkaitan dengan masalah dan tujuan penelitian; (2) Observasi atau pengamatan terhadap aktivitas keagamaan dan interaksi sosial antar umat beragama; (3) Wawancara dengan sejumlah informan yang terdiri dari tokoh/pemuka/pemimpin agama dan tokoh adat, para pejabat pemerintah setempat yang terkait serta tokoh-tokoh pemuka pendapat lainnya yang dipandang memiliki informasi yang dibutuhkan. Informasi yang terhimpun diolah dan dianalisis dengan teknik analisis deskriptif kualitatif.

Kerangka pemikiran yang melandasi penelitian ini ialah bahwa konflik sosial bernuansa agama yang terjadi di berbagai daerah beberapa tahun yang lalu, walaupun telah berhasil ditanggulangi bersama oleh pemerintah dan pihak-pihak terkait, betapapun telah meninggalkan berbagai masalah dalam hubungan antar umat beragama setempat. Setidaknya telah terjadi hubungan yang sangat hati-hati atau bahkan kurang harmonis yang selanjutnya mempengaruhi aktivitas keagamaan dan interaksi sosial umat beragama. Karena itu, upaya memelihara harmonisasi dan kerukunan umat beragama perlu digalakkan terus, terutama di tingkat lokal dengan mengikutsertakan semua pihak terkait, baik dari unsur pemerintah maupun dari unsur masyarakat dan/atau umat beragama.

Seiring dengan dinamika kehidupan dan semakin kompleksnya persoalan kerukunan maka upaya penanganan perlu dikembangkan dan diarahkan pada perwujudan rasa kemanusiaan dengan kebijakan "pengembangan wawasan multikultural" serta dengan pendekatan yang lebih bersifat "bottom up".

\section{RUJUKAN TEORI}

Dalam rangka operasionalisasi kerangka berfikir yang dikemukakan pada bagian I di atas maka penelitian yang dilaporkan ini merujuk kepada Teori Fungsional, Teori Interaksi Sosial, dan Teori Konflik.

Teori Fungsional atau Struktural digunakan untuk menjelaskan fenomena aktivitas keagamaan masyarakat yang antara lain untuk 
melanggengkan kerukunan intern umat beragama sebagai bagian dari upaya mempertahankan integritas masyarakat. Teori Fungsional melihat bahwa masyarakat adalah suatu sistem yang stabil yang terdiri atas kelompokkelompok yang selalu bekerja sama. Agama sebagai salah satu bagian dari struktur sosial, berfungsi mempertahankan integritas sistem sosial. Teori ini juga dijadikan acuan untuk menggali dan menjelaskan partisipatif aktif masyarakat, baik yang diperankan oleh tokoh/pemimpin agama dan tokoh/ pemimpin masyarakat dan adat dalam upaya penanganan masalah dan pembinaan kerukunan umat beragama dengan pendekatan "bottom up". Menurut teori ini ketertiban sosial itu merupakan hasil usaha tidak sadar dari orang-orang yang mengorganisir kegiatan-kegiatan mereka secara produktif (Sudjangi, 2003:14).

Teori Interaksi Sosial digunakan untuk menjelaskan hubunganhubungan antar umat beragama dalam melakukan kegiatan interaksi dalam berbagai bidang kehidupan, antara lain dalam bidang sosial budaya. bidang ekonomi, dan bidang politik serta ke arah mana kecenderungan sifat dan bentuk interaksi yang dilakukan itu; apakah ke arah kerjasama \{cooperation), ke arah kompetisi (competition), atau persaingan, ataukah ke arah pertikaian (conflik), ataukah ke arah akomodasi (accommodation) (Soemardjan, 1974:7).

Teori Konflik digunakan untuk menjelaskan mengapa dan/atau bagaimana konflik sosial bernuansa agama itu sering terjadi dalam masyarakat, serta peran apa yang dimainkan/dilakukan oleh pemerintah yang memiliki kekuasaan dalam upaya penanganan masalah dan pembinaan kehidupan umat beragama pasca konflik di daerah masing-masing. Teori konflik melihat bahwa masyarakat adalah suatu sistem yang tidak stabil, terdiri atas kelompok4x;elompok dan kelas-kelas yang saling bertentangan. Karena itu, teori konflik melihat bahwa ketertiban sosial dihasilkan dan dipertahankan oleh pemaksa yang terorganisir oleh kelas-kelas yang dominan. Kewenangan untuk memaksa, dalam kehidupan kita bermasyarakat dan bernegara terutama demi menjaga tegaknya integrasi nasional, ada pada pihak pemerintah (Sudjangi, 2003: 14).

\section{SKETSA LOKASI PENELITIAN}

Kota Surabaya terletak antara $07.21^{\circ}$ Lintang Selatan dan $112.36^{\circ}$ sampai dengan 112.54 Bujur Timur. Wilayahnya merupakan dataran rendah dengan ketinggian 3 sampai 6 meter di atas permukaa:, :aut, kecuali di sebelah selatan dengan ketinggian 25 sampai 50 meter. Sebagian areal tanah Surabaya 
terdiri atas tanah aluvial, hasil endapan sungai dan pantai. Di bagian barat terdapat perbukitan yang mengandung kadar kapur tinggi.

Penduduk Surabaya terbilang sangat padat dan plural serta menjadi titik pertemuan orang dari kawasan regional dan global dengan berbagai latar belakang masing-masing. Menurut data dari Dinas Pendaftaran Penduduk dan Pencatatan Sipil bulan Mei 2004, jumlah penduduk Surabaya sebanyak 2.616.845 jiwa. Dari jumlah tersebut, 49,55\% adalah laki-laki, sedangkan selebihnya adalah perempuan. Bila dirinci menurut agama yang dipeluk maka perbandingannya adalah sebagai berikut: (1) Islam 2.142.449 jiwa atau $81,87 \%$; (2) Protestan 242.661 jiwa atau 9,27\%; (3) Katholik 132.436 jiwa atau 5,06\%; (4) Hindu 52.765 jiwa atau 2,02\%; dan (5) Budha 46.026 jiwa atau $21,75 \%$ (Sya'roni, 2004)

Kota Surabaya yang luasnya lebih $320 \mathrm{Km}^{2}$ itu hampir $80 \%$ wilayahnya atau lebih kurang 29.000 hektar merupakan daratan. Dari jumlah itu, 773,6 hektar adalah lahan persawahan dan 4.397 hektar lahan perladangan. Sekitar 23.000 hektar atau $85 \%$ dari luas wilayah Surabaya digunakan untuk lokasi permukiman, perumahan, dan bangunan lainnya, termasuk lahan kegiatan ekonomi seperti industri dan perdagangan (GAFURA, T.th.: 25-25).

Pusat kota Surabaya dipenuhi dengan bangunan-bangunan modern seperti apartemen, hotel, pusat-pusat perbelanjaan dan lain-lain. Kegiatan bisnis berlangsung seperti tak ada hentinya sehingga pantaslah kalau Surabaya memiliki status atau julukan sebagai kota industri dan kota dagang.

Pertumbuhan pesat kota Surabaya sebagai kota industri dan perdagangan tidaklah serta merta membuat warga Surabaya kehilangan kesantunan dan sikap saling menghargai di antara warganya yang justru menjadi ciri khas kekerabatan. Salah satu aset besar kota Surabaya ialah kekritisan warganya, suatu sikap yang layak dihargai sebagai sebuah kelebihan dan bukan penghambat kemajuan pembangunan. Sikap kritis ini merupakan salah satu ciri yang melekat pada "arek-arek Suroboyo". Tampaknya posisi strategis Surabaya yang menjadi titik pertemuan orangorang lokal, nasional, dan global memberikan corak hetrogenitas pada masyarakatnya dan corak itu lambat laun membentuk sifat khas orang Surabaya yang disebut "arek-arek Suroboyo" seperti pragmatis, egaliter, terbuka, lugas, tidak banyak basa-basi, dan kritis.

Dengan penduduk yang padat dan plural serta menjadi titik pertemuan orang dari kawasan regional, nasional, dan global, membawa 
dampak pada kompleksitas persoalan yang harus ditangani pemerintah kota dan jajarannya. Layanan masyarakat, tata ruang kota, transportasi, pendidikan, banjir, polusi, patologi sosial, adalah contoh-contoh persoalan yang sampai kini tetap menjadi perhatian serius pemerintah kota Surabaya untuk mengoptimalkan upaya penanganannya. ${ }^{\circ}$

Mayoritas $(81,87 \%)$ penduduk Surabaya menganut agama Islam, dan selebihnya menganut agama Protestan $(9,27 \%)$, Katholik $(5,06 \%)$, Hindu (2,02\%), dan Budha (1,75\%). Mereka memiliki rumah-rumah ibadah tempat melakukan kegiatan ibadah/ritual keagamaan, seperti: masjid dan mushallah (Islam), sebanyak 937 dan 1.521 buah, gereja Protestan sebanyak 312 buah, gereja Katholik sebanyak 16 buah, pure Hindu sebanyak 7 buah, dan vihara Budha sebanyak 26 buah.

Para tokoh dan pemuka agama dari masing-masing agama membentuk majelis-majelis agama seperti Majelis Ulama Indonesia (MUI) di kalangan tokoh agama Islam, Persekutuan Gereja Indonesia (PGI) di kalangan tokoh agama Kristen Protestan, Majelis Wali Agama Indonesia (MAWI) dikalangan tokoh agama Katholik, Persatuan Hindu Dharma Indonesia (PHDI) di kalangan tokoh agama Hindu, dan Wali Umat Budha Indonesia (WALUBI) di kalangan tokoh agama Budha. Majelis-majelis agama tersebut banyak berperan dalam mengatur hubungan antara kelompok agama masing-masing dengan pemerintah dan hubungan antar kelompok umat beragama itu sendiri.

Selain majlis-majlis agama, terdapat pula berbagai lembaga keagamaan operasional yang dimiliki masing-masing kelompok agama, seperti lembaga yang bergerak di bidang pendidikan, bidang penerangan/ dakwah, dan bidang-bidang lain termasuk yang bergerak di bidang santunan sosial. Di kalangan umat Islam terdapat organisasi keagamaan Nahdlatul Ulama (NU) dan Muhammadiyah, keduanya merupakan organisasi keagamaan terbesar di Surabaya. Belakangan ini muncul organisasi keagamaan Islam yang relatif baru di kalangan umat Islam Surabaya yakni organisasi Hizbut Tahrir yang banyak digandrungi kalangan muda-mudi dan mahasiswa dari perguruan tinggi umum. Sementara itu, dari kalangan umat beragama lain tidak tampak adanya organisasi keagamaan baru, kecuali organisasi keagamaan yang telah ada selama ini. 


\section{KEADAAN KEHIDUPAN BERAGAMA PASCA KONFLIK}

\section{A. Aktivitas Keagamaan}

Aktivitas keagamaan yang diamati dalam penelitian yang dilaporkan ini adalah aktivitas keagamaan intern masing-masing (pemeluk) agama yang aspek-aspeknya meliputi: pelaksanaan ibadah, pendiri tempat/rumah ibadah, penerangan atau dakwah agama, dan perayaan hari besar keagamaan. Informasi yang diperoleh di sini ialah suasana pelaksanaan kegiatan-kegiatan keagamaan yang dimaksud, apakah berlangsung dengan aman dan tenang serta apakah umat beragama lain di sekitarnya tidak merasa terganggu dengan pelaksanaan kegiatan keagamaan dimaksud.

Masing-masing kelompok agama yang diamati, menyatakan bahwa pelaksanaan kegiatan keagamaan khususnya kegiatan ibadah di tempat/ rumah ibadah masing-masing berjalan dengan tenang dan aman tanpa merasakan adanya gangguan dari kegiatan umat beragama lain. Umat beragama lain yang berada di sekitar tempat pelaksanaan kegiatan keagamaan dimaksud juga menyatakan tidak merasa terganggu oleh kegiatan keagamaan tersebut. Bentuk-bentuk kegiatan keagamaan yang dimaksud meliputi: salat berjamaah di masjid bagi umat Islam termasuk salat Jumat dan salat dua hari raya; kegiatan ibadah di gereja-gereja umat Kristiani; kegiatan ibadah di pure dan vihara bagi umat Hindu dan Budha.

Menurut keterangan Kepala Kantor Departemen Agama Kota Surabaya Drs. H. Ahmad Sya'roni bahwa suasana kondusif melaksanakan kegiatan keagamaan intern dengan tenang, aman, tanpa merasa terganggu satu dengan lain, bagi umat beragama di Surabaya, sangat ditopang oleh saling pengertian bagi antar umat beragama itu sendiri, terutama para tokoh dan pemimpin agama yang pada umumnya adalah orang-orang yang mengerti dan faham serta sadar terhadap kenyataan penduduk Surabaya berlatar belakang pluralitas. Mereka mengerti dan sadar bahwa pluralisme agama merupakan kenyataan histori yang justru menyemangati pertumbuhan Surabaya selama ini.

Keluhan yang mengesankan adanya rasa terganggu, muncul di kalangan sesama/intern umat Islam ketika melaksanakan kegiatan ibadah yang sama dalam waktu bersamaan. Gangguan ini dimaksud berupa gangguan suara yang dialami sekelompok umat Islam yang sedang melaksanakan ibadah (misalnya shalat Jumat) di salah satu masjid dan pada waktu bersamaan kelompok umat Islam lain di masjid berdekatan juga melaksanakan kegiatan ibadah yang sama. Jadi ada gangguan suara yang bersumber dari sistem penggunaan alat pembesar suara (sound system). 
Pembangunan rumah-rumah ibadah oleh umat beragama di Surabaya terkadang menimbulkan ketegangan hubungan antar umat beragama tertentu. Kasus yang terkadang terjadi ialah pembangunan gereja, terutama Gereja Protestan yang diprotes umat Islam di sekitar lokasi pembangunan gereja tersebut. Di satu pihak umat Kristen Protestan mendiri gereja di lokasi tertentu untuk memenuhi kebutuhan beribadah mereka, sementara di pihak lain umat Islam di sekitar lokasi itu memprotes pembangunan gereja tersebut karena lokasi itu berada di tengah-tengah komunitas umat Islam, sedangkan umat Kristen Protestan yang bermukim di lokasi itu hanya beberapa keluarga saja. Tampaknya aturan main yang ada berkaitan dengan pendirian rumah-rumah ibadah, ditanggapi dengan persepsi yang berbeda antara kelompok umat Islam dan kelompok umat Kristen Protestan setempat.

Umat Kristen Protestan di Indonesia terbagi ke dalam banyak sekte/ aliran dan setiap sekte memiliki gereja sendiri. Boleh jadi suatu lokasi tertentu terdapat 110 orang umat Kristen Protestan tetapi di tempat itu berdiri 3 buah gereja. Kenyataan demikian ini yang diprotes umat Islam setempat. Pada hal adanya 3 buah gereja di tempat itu karena umat Kristen Protestan yang ada terdiri atas 3 sekte dan masing-masing sekte telah mencapai minimal 32 orang maka mereka telah berhak mendiri sebuah gereja. Umat Katholik tidak memiliki sekte/aliran dan untuk dapat mendirikan gereja di suatu lokasi pemukiman, dil okasi itu minimal terdapat 5.000 orang Katholik.

Walaupun kasus seperti dikemukakan di atas, dalam masa tiga tahun terakhir tidak lagi terjadi di Surabaya, namun pihak berwenang, dalam hal ini Kantor Departemen Agama Kota Surabaya selalu memprogramkan kegiatan sosialisasi dan pemberian penjelasan mengenai aturan-aturan main yang terkait terutama isi SKB Mendagri dan Menag Nomor 01/BER/MinMag/1969 tentang Pelaksanaan Tugas Aparatur Pemerintahan dalam Menjamin Ketertiban dan Kelancaran Pelaksanaan Pengembangan dan Ibadat Agama bagi pemeluk-pemeluknya.

Kegiatan penerangan agama dilakukan baik secara internal maupun secara eksternal. Dimaksudkan dengan kegiatan penerangan agama secara internal ialah kegiatan pelajaran, pendidikan, dan sosialisasi ajaran agama bersangkutan kepada umatnya agar umat mengetahui/memahami, menghayati, dan mengamalkan ajaran-ajaran agama masing-masing. Sedangkan kegiatan penerangan agama secara eksternal ialah kegiatan memperkenalkan, mempengaruhi, dan mengajak orang lain yang belum menganut suatu agama agar bersedia dan rela atas kesadaran sendiri memeluk agama yang ditawarkan itu. 
Menurut keterangan Kepala Kantor Departemen Agama Kota Surabaya bahwa kegiatan penerangan agama yang dilakukan pemeluk agama yang pada umumnya lebih bersifat internal, sejak era reformasi, tidak menimbulkan masalah dalam hubungan antar umat beragama. Hal itu ditunjukkan oleh tidak adanya pengaduan dari masyarakat atau umat beragama yang merasa dirugikan oleh tata cara penerangan/penyiaran agama yang tidak fair.

Peringatan hari-hari besar keagamaan, bagi bangsa Indonesia tampaknya telah berakar dan melembaga dalam kehidupan dan budaya bangsa. Terutama di kalangan instansi pemerintah, sipil dan militer, swasta, sekolah-sekolah, dan bahkan sebagian masyarakat umum. Dewasa ini, hampir setiap hari atau tanggal yang bertepatan dengan hari-hari besar keagamaan dinyatakan (oleh pemerintah) sebagai hari libur nasional.

Pelaksanaan kegiatan hari-hari besar keagamaan di Surabaya selama ini, terutama setelah "aturan main" yang ditetapkan pemerintah tersosialisasikan secara meluas di kalangan tokoh dan umat beragama, tidak menimbulkan masalah dalam hubungan antar umat beragama.

\section{B. Interaksi Sosial Umat Beragama}

Dalam penelitian ini, dimaksudkan dengan interaksi sosial umat beragama ialah hubungan-hubungan yang terjadi dalam kehidupan keseharian umat beragama yang secara simpel dikelompokkan ke dalam bidang sosial budaya, ekonomi, dan politik.

Tidak diperoleh informasi tentang adanya gangguan kerukunan umat beragama yang bersumber dari adanya propaganda keagamaan lewat kegiatan pelayanan pendidikan formal dan kegiatan pelayanan kesehatan di pusat-pusat pelayanan kesehatan. Dalam kegiatan pendidikan formal, bahkan ada hal yang menarik. Sekolah Santa Maria, sebagai salah satu sekolah swasta Katholik yang Favorit di Surabaya, pada bulan Ramadhan 1425 H yang lalu mengadakan "Pondok Ramadhan" untuk melayani kebutuhan pendidikan agama Islam bagi siswa-siswa yang beragama Islam.

Dalam kegiatan pelayanan kesehatan, tampaknya penduduk Surabaya yang seluruhnya adalah umat beragama pada umumnya menyadari bahwa pelayanan kesehatan adalah suatu tugas kemanusiaan. Sehingga sangat jarang terjadi, setidaknya dalam masa lima tahun terakhir, adanya nada sumbang yang mengesankan bahwa pelayanan kesehatan dijadikan peluang dan kesempatan oleh pemeluk agama tertentu untuk mempengaruhi orang atau kelompok beragama lain untuk beralih agama. 
Dalam kegiatan pelayanan atau santunan sosial, kesan adanya "propaganda agama" terkadang muncul kepermukaan. Hal itu terjadi bila kegiatan santunan sosial dilakukan secara berkelompok oleh pemeluk agama tertentu dengan menggunakan simbol-simbol keagamaan mereka, sementara sasarannya adalah umat beragama lain. Pelayanan atau santunan sosial pada dasarnya merupakan wujud pengamalan ajaran agama di bidang sosial misalnya santunan kepada golongan miskin dan/atau mereka yang terkena bencana alam dan musibah lainnya. Karena itu, untuk menghindari adanya kesan "propaganda agama" sebaiknya upaya tersebut dilakukan tanpa menggunakan simbol-simbol keagamaan dan ditujukan kepada sasaran dengan latar belakang berbagai agama, termasuk pemeluk agama yang sama dengan pihak yang memberikan santunan sosial.

Dalam kegiatan ekonomi, yang justru mewarnai kehidupan Surabaya sebagai kota metropolitan, tampaknya juga tidak menampakkan adanya sekat-sekat berlatar belakang primordialisme, termasuk perbedaan agama. Interaksi masyarakat dalam kegiatan ekonomi, baik yang bersifat mikro maupun makro, pada umumnya lebih didasarkan pada tuntutan kebutuhan yang bersifat ekonomi itu sendiri.

Dalam kegiatan politik (yang dalam konteks ini dibatasi cakupannya pada kegiatan politik praktis di partai politik dan di lembaga eksekutif dan legislatif), tidak tampak adanya keluhan yang mengemuka tentang adanya perlakuan diskriminatif dan pilih kasih karena perbedaan agama. Prestasi politik yang diraih seseorang dalam kegiatan-kegiatan tersebut diperoleh melalui mekanisme wajar. Setiap warga memiliki hak dan kewajiban politik yang sama dalam kegiatan kehidupan bernegara, berbangsa, dan bermasyarakat tanpa membedakan latar belakang agama yang dianutnya.

\section{PEMELIHARAAN KERUKUNAN UMAT BERAGAMA}

\section{A. Peran Pemerintah}

Kerukunan hidup beragama sebagai bagian dari kerukunan hidup berbangsa dan bernegara dalam Negara Kesatuan Republik Indonesia secara konstitusional merupakan kewajiban dan tanggung jawab pemerintah untuk menjaga dan memeliharanya. Namun demikian, masyarakat yang pada umumnya terdiri dari umat beragama, tentu saja merasa berkepentingan terhadap terciptanya suasana kerukunan dalam melakukan interaksi sosial. Karena itu umat beragama juga memiliki tanggungjawab untuk menjaga dan memelihara kerukunan hidup dalam masyarakat, termasuk kerukunan umat beragama itu sendiri. 
Kewajiban dan tanggungjawab memelihara kerukunan hidup beragama dalam masyarakat, dalam aplikasinya menuntut peran-peran yang relevan dengan posisi, tugas dan kewenangan masing-masing pihak, baik pemerintah maupun masyarakat.

Dalam penelitian ini, peran pemerintah diamati lewat peran instansi Departemen Agama dan pemerintah daerah setempat serta instansi pemerintah lain yang memiliki kepedulian. Kongkritnya ialah Kantor Departemen Agama Kota Surabaya, Pemerintah Surabaya, dan Universitas Islam Negeri (UIN) Sunan Ampel Surabaya khususnya Fakultas Ushuluddin.

Kantor Departemen Agama Kota Surabaya memiliki peran sentral dalam upaya pemeliharaan kerukunan umat beragama di Surabaya. Tuntutan itu bersumber dari Surat Keputusan Menteri Agama RI Nomor 373 Tahun 2002 yang antara lain menyebutkan bahwa salah satu fungsi Kantor Departemen Agama Kabupaten/Kota ialah memberikan pelayanan dan bimbingan di bidang kerukunan umat beragama.

Dalam kaitan dengan Rencana Strategik (Renstra) Kota Surabaya 2003 - 2005 maka fungsi tersebut dirumuskan dalam bentuk misi yakni "memperkokoh kerukunan intern dan antar umat beragama". Misi tersebut kemudian dijabarkan dalam bentuk program yakni "Program Peningkatan Kerukunan Hidup Intern dan Antar Umat Beragama". Kegiatan-kegiatan operasional yang dilaksanakan tahun 2004 - 2005 difokuskan pada membina kerukunan intern dan antar umat beragama yang dilakukan melalui kunjungan silaturrahmi, dialog dan temu ilmiah secara rutin antar pemuda, siswa, mahasiswa, perempuan, cendekiawan, pemuka, dan tokoh umat beragama. Juga melakukan koordinasi dan memfasilitasi berbagai badan/lembaga lokal yang memiliki kepedulian dan/atau yang dibentuk khusus untuk turut serta menjaga dan memelihara kerukunan umat beragama di Surabaya.

Sesungguhnya hubungan antar umat beragama di Surabaya selama ini secara umum relatif berlangsung dalam suasana saling menghormati, toleransi, tenggang rasa dan semua pihak menginginkan jalinan hubungan dan interaksi sosial yang kooperatif dan akomodatif. Para tokoh dan pemuka agama pada umumnya adalah mereka yang terdidik dan penuh pengertian. Karena itu bila terjadi letupan-letupan kecil dalam kaitan hubungan antar umat beragama, dengan segera dapat diredam sehingga konflik relatif tidak dapat mengemuka. Namun demikian, dalam hubungan intern umat Islam akhir-akhir ini terkadang muncul kasus-kasus yang mengakibatkan ketegangan hubungan walaupun pada akhirnya sumber kasus dapat diatasi dan ditemukan solusinya. 
Pemerintah Kota Surabaya, dalam kaitan dengan pembinaan kehidupan beragama di wilayahnya pada era otonomi daerah telah menetapkan Program Pemahaman dan Pengamalan Nilai Keagamaan yang cakupannya meliputi kegiatan-kegiatan sebagai berikut:

a. Bantuan kegiatan pembinaan umat beragama dan multikulturalisme

b. Bantuan penunjang lembaga keagamaan

c. Bantuan rehabilitasi rumah ibadah

d. Peringatan hari besar keagamaan

e. Pembinaan qari'/qariah

f. Bantuan perjalanan haji bagi Tim Pembimbing Haji Daerah.

Penerapan program kegiatan tersebut, khususnya yang berkaitan dengan upaya pembinaan kerukunan umat beragama, berupa mendorong, mengkoordinasikan, dan memberi bantuan, baik kepada instansi terkait (terutama Kantor Departemen Agama Kota Surabaya dan jajarannya) maupun kepada masyarakat melalui wadah/organisasi kegiatan masyarakat yang terkait. Setidaknya ada empat wadah kegiatan masyarakat Surabaya yang memfokuskan perhatian pada upaya pembinaan kerukunan hidup masyarakat, termasuk kerukunan hidup beragama. Keempat wadah dimaksud masing-masing:

1. Forum Komunikasi Pelajar Antar Agama Surabaya, disingkat Forplas.

2. Forum Komunikasi Mahasiswa Antar Agama Surabaya, disingkat FIMAS.

3. Forum Lintas Agama Surabaya, disingkat Forlas.

4. Forum Komunikasi Elemen Masyarakat Surabaya, disingkat Forkemas.

Selain kedua instansi pemerintah (Kantor Departemen Agama Kota Surabaya dan Pemerintah Daerah/Kota Surabaya) tersebut, sebuah lembaga perguruan tinggi di Surabaya yakni Fakultas Ushuluddin IAIN Sunan Ampel Surabaya tampil pula menyodorkan gagasan perlunya dilakukan dialog antar komponen umat beragama. Gagasan yang diajukan itu mendapat respon positif dari para tokoh/pemuka agama di daerah ini (Kristen, Katholik, Hindu, Budha, dan Khong $\mathrm{Hu} \mathrm{Cu}$ ).

Implementasi awal dari gagasan dialog tersebut ialah terlaksananya Lokakarya dan Musyawarah Antar Agama se Jawa Timur tanggal 19 Oktober 2001 yang ditangani oleh sebuah panitia yang beranggotakan unsur Fakultas Ushuluddin IAIN Sunan Ampel dan tokoh-tokoh dari lain agama di daerah ini. Salah satu hasil penting dari Lokakarya dan musyawarah tersebut ialah kesepakatan untuk membentuk suatu forum bersama yang diberi nama Forum Interaksi antar Agama (FIA) lengkap dengan visi, misi, dan program kerjanya. 
FIA dibentuk dalam rangka mencari titik temu agama-agama dari tataran teologis (keimanan) menuju proaksi sosial dengan mengaktualisasikan dalam kehidupan nyata umat beragama. Di samping itu FIA berusaha mencari pola pembinaan kerukunan umat antaragama secara efektif dan prospektif dengan titik tekan pada peningkatan kerja sama nyata, baik generasi muda maupun akar rumput pemeluk setiap agama dalam menghadapi tantangan masa depan dan turut serta secara aktif menyumbangkan nilai-nilai religiusitas dalam kehidupan berbangsa dan bernegara.

Kegiatan monumental penting lainnya yang dilaksanakan FIA ialah Seminar Nasionalisme dalam Perspektif Agama-Agama dilaksanakan tanggal 27 Oktober 2002 di Wisma Perwira TNI AL Juanda.

Tema seminar diangkat karena saat itu sedang berkembang wacana dari berbagai daerah yang ingin melepaskan diri dari NKRI, berbarengan dengan bermunculannya konflik horizontal di berbagai daerah yang pada umumnya memiliki nuansa perbedaan agama. Seminar merasa perlu mengkaji kembali mengapa semua itu terjadi, apakah nasionalisme hanya semangat perjuangan ataukah nasionalisme merupakan sebuah keharusan, serta bagaimana nasionalisme menurut kaca mata agama-agama?

Peserta seminar berjumlah 100 orang dengan rincian:

- Unsur Pemuka Agama : 25 orang

- Unsur Akademisi : 20 orang

- Unsur Birokrasi : 10 orang

- Unsur Milker : 5 orang

- Unsur Pemuda/Mahasiswa : 30 orang

- Unsur LSM : 10 orang.

Nara Sumber seminar adalah: (1) Prof. DR. H. Alwi Shihab, MA Dosen Harvard University; (2) DR. Th. Sumarthana, cendekiawan Protestan; (3) DR. Naya Sujana, MA Akademisi Universitas Airlangga Surabaya; (4) Tokoh-tokoh dari berbagai agama di Jawa Timur (Islam, Protestan, Katholik, Hindu, Budha, dan Khong $\mathrm{Hu} \mathrm{Cu}$ ).

Tokoh sentral di Fakultas Ushuluddin IAIN Sunan Ampel Surabaya yang kreatif mengagas berbagai pendekatan dalam rangka kerukunan umat beragama ialah Dekan sendiri yang ketika itu dijabat oleh DR. A. Khozin Afandi. Berbagai program yang disodorkan ke tingkat pemerintah Provinsi Jawa Timur, melalui FIA antara lain

Seminar nasional tentang (agama) Khong $\mathrm{Hu} \mathrm{Cu}$.

Festifal budaya antar umat beragama dengan berbagai kegiatan, antara .lain festifal drum band, festifal lagu-lagu daerah bernuansa agama, 
FIA dibentuk dalam rangka mencari titik temu agama-agama dari tataran teologis (keimanan) menuju proaksi sosial dengan mengaktualisasikan dalam kehidupan nyata umat beragama. Di samping itu FIA berusaha mencari pola pembinaan kerukunan umat antaragama secara efektif dan prospektif dengan titik tekan pada peningkatan kerja sama nyata, baik generasi muda maupun akar rumput pemeluk setiap agama dalam menghadapi tantangan masa depan dan turut serta secara aktif menyumbangkan nilai-nilai religiusitas dalam kehidupan berbangsa dan bernegara.

Kegiatan monumental penting lainnya yang dilaksanakan FIA ialah Seminar Nasionalisme dalam Perspektif Agama-Agama dilaksanakan tanggal 27 Oktober 2002 di Wisma Perwira TNI AL Juanda.

Tema seminar diangkat karena saat itu sedang berkembang wacana dari berbagai daerah yang ingin melepaskan diri dari NKRI, berbarengan dengan bermunculannya konflik horizontal di berbagai daerah yang pada umumnya memiliki nuansa perbedaan agama. Seminar merasa perlu mengkaji kembali mengapa semua itu terjadi, apakah nasionalisme hanya semangat perjuangan ataukah nasionalisme merupakan sebuah keharusan, serta bagaimana nasionalisme menurut kaca mata agama-agama?

Peserta seminar berjumlah 100 orang dengan rincian:

- Unsur Pemuka Agama : 25 orang

- Unsur Akademisi : 20 orang

- Unsur Birokrasi : 10 orang

- Unsur Militer : 5 orang

- Unsur Pemuda/Mahasiswa : 30 orang

- Unsur LSM : 10 orang.

Nara Sumber seminar adalah: (1) Prof. DR. H. Alwi Shihab, MA Dosen Harvard University; (2) DR. Th. Sumarthana, ^endekiawan Protestan; (3) DR. Naya Sujana, MA Akademisi Universitas Airlangga Surabaya; (4) Tokoh-tokoh dari berbagai agama di Jawa Timur (Islam, Protestan, Katholik, Hindu, Budha, dan Khong $\mathrm{Hu} \mathrm{Cu}$ ).

Tokoh sentral di Fakultas Ushuluddin IAIN Sunan Ampel Surabaya yang kreatif mengagas berbagai pendekatan dalam rangka kerukunan umat beragama ialah Dekan sendiri yang ketika itu dijabat oleh DR. A. Khozin Afandi. Berbagai program yang disodorkan ke tingkat pemerintah Provinsi Jawa Timur, melalui FIA antara lain

Seminar nasional tentang (agama) Khong $\mathrm{Hu} \mathrm{Cu}$.

Festifal budaya antar umat beragama dengan berbagai kegiatan, antara lain festifal drum band festifal lagu-lagu daerah bernuansa agama, 
perlombaan membuat karangan/uraian tentang kerukunan umat beragama. Namun demikian, gagasan-gagasan tersebut tidak pernah terlaksana karena hambatan dana dan kurang mendapat respon dari pejabat terkait (dalam hal ini Kanwil Departemen Agama dan Pemda Provinsi Jawa Timur), sampai kemudian terbentuknya Forum Komunikasi Antar Umat Beragama (FKAUB) tingkat Provinsi Jawa Timur pada tahun 2002 berdasarkan Surat Keputusan Gubernur Jawa Timur Nomor 188/106/KPTS/013/2002, tanggal 18 April 2002.

\section{B. Peran Masyarakat}

Selama ini, masyarakat Surabaya yang merasa tergugah untuk berperan serta dalam upaya pembinaan kerukunan umat beragama tidak melakukan perkelompok dan/atau perelemen masyarakat, melainkan secara bersama-sama antar berbagai kelompok dan elemen masyarakat. Salah satu pertimbangan (sesuai kesepakatan mereka) ialah agar tidak terjadi kompetisi kegiatan yang dapat menjurus kepada kompetisi tidak sehat (kalau dilakukan perkelompok). Maka muncullah kemudian berbagai wadah bersama yang pada umumnya lebih bersifat forum konsultasi, seperti antara lain Forum Lintas Agama Surabaya (disingkat Forlas), Ikatan Kerukunan Umat Beragama (IKUB), dan Forum Komunikasi Elemen Masyarakat (Forkemas).

Salah seorang tokoh Katholik di Surabaya, Drs. Romo Eko Y. Budi Susilo, Pr. mengatakan bahwa pembentukan berbagai macam wadah komunikasi yang fungsinya hampir sama itu menunjukkan bahwa masyarakat Surabaya dan Jawa Timur pada umumnya cukup responsif dan pro aktif melakukan upaya yang bersifat "bottom up" dalam upaya menjaga dan memelihara kerukunan umat beragama di daerah ini.

Setelah terbentuknya FKAUB Jawa Timui (tingkat provinsi dan tingkat kabupaten/kota) maka seluruh kegiatan pemeliharaan kerukunan umat beragama di tingkat provinsi ditangani langsung oleh wadah ini yang memang memiliki fasilitas yang dibutuhkan (dana dan fasilitas lain). Sejak terbentuknya hingga tahun 2005, FKAUB provinsi telah melakukan dialog, musyawarah, dan semacamnya berbagai lapisan masyarakat seperti:

tokoh-tokoh agama

mahasiswa

pelajar tingkat SMU

LSM perempuan.

dengan peserta terdaftar lebih 6.000 orang. 
Ditambahkan bahwa FKAUB tingkat kabupaten/kota telah terbentuk di 35 kabupaten/kota dari sejumlah 38 kabupaten/kota se Jawa Timur. Tiga daerah lainnya yang belum membentuk FKAUB masing-masing Surabaya, Gresik, dan Sidoarjo. Ketiga daerah saling berbatasan dimana Kota Surabaya yang menjadi pusat kegiatan FKAUB tingkat Provinsi Jawa Timur selama ini sering pula mengikutkan peserta dari dua daerah lainnya. Khusus Kota Surabaya, keberadaan berbagai wadah kerukunan bentukan masyarakat seperti dikemukakan di atas menjadi salah satu pertimbangan belum terbentuknya FKAUB di daerah ini.

Bentuk-bentuk kegiatan yang dilakukan FKAUB provinsi seperti dikemukakan di atas, telah dilakukan pula oleh forum kerukunan lokal Surabaya, walaupun frekuensinya masih kurang. Namun demikian, kalau FKAUB provinsi selama ini lebih menekankan kegiatannya pada acaraacara dialog, musyawarah, dan seminar maka berbagai wadah kerukunan lokal Surabaya bentukan masyarakat telah menjangkau kegiatan-kegiatan operasional yang bersentuhan dengan kebutuhan masyarakat seperti santunan sosial, pengobatan cuma-cuma, sunnatan massal, kawin massal, dan pergelaran seni. Sebuah wadah operasional bentukan masyarakat yang banyak melakukan kegiatan-kegiatan tersebut ialah Pondok Kasih.

Dalam kaitan dengan pelaksanaan Pilkada (Pemilihan Walikota dan Wakil Wali Kota Surabaya) tanggal 27 Juni 2005, umat beragama di Surabaya, melalui organisasi/lembaga kerukunan lokal dan tokoh-tokoh agama serta di bawah koordinasi pemerintah daerah setempat mengadakan "doa bersama" yang diikuti oleh seluruh unsur dan elemen masyarakat serta kelompok agama yang ada.

\section{Faktor Pendukung dan Penghambat}

Suasana kerukunan hidup, baik dalam kehidupan beragama maupun kehidupan bermasyarakat pada umumnya merupakan kebutuhan semua orang, baik secara perorangan maupun kelompok. Sebaliknya, suasana ketidakrukunan pada dasarnya tidak diinginkan dan karenanya ingin dihindarkan setiap orang dalam kehidupan pergaulan dan interaksi sosial.

Adanya sistem pengaturan dalam kehidupan bersama, baik yang mewujud dalam aturan adat, maupun ajaran agama, demikian pula ketentuan/ peraturan perundang-undangan negara/daerah, merupakan upaya sadar manusia untuk menciptakan suasana kerukunan dalam kehidupan bersama itu. Sebaliknya, konflik dan kerusuhan yang terjadi dalam suatu kehidupan 
bersama, betapapun hebatnya, pada akhirnya akan reda dan ditemukan solusi ke arah kehidupan yang akomodatif dan perdamaian.

Filosofi yang dikemukakan di atas, juga dialami oleh masyarakat Surabaya dan Jawa Timur pada umumnya. Berbagai kasus konflik yang pernah terjadi, seperti pembakaran gereja, pendirian rumah-rumah ibadah, kasus dukun santet, konflik antar etnik, kasus penyelewengan ajaran agama, yang pernah terjadi di Jawa Timur dalam rentang waktu satu dekade dan dampak yang ditimbulkannya masih dirasakan oleh sebagian masyarakat yang mengalaminya.

Namun demikian, akibat dan dampak yang ditimbulkan oleh konflikkonflik yang terjadi itu menyadarkan semua pihak untuk kemudian melakukan upaya pencegahan secara dini. Pihak pemerintah, terutama yang terkait, merumuskan aturan dan menentukan kebijakan yang relevan, pemuka agama dan tokoh masyarakat membentuk wadah kerjasama lintas agama dan elemen masyarakat serta kemudian mengaktifkannya. Hal-hal itulah yang dipandang sebagai faktor pendukung terpeliharanya suasana kerukunan umat beragama, terutama kerukunan umat antar agama di Surabaya dan Jawa Timur pada umumnya.

Hal lain yang sangat mendukung terciptanya suasana kerukunan masyarakat di daerah ini ialah apa yang dipandang sebagai ciri atau sifat khas orang Surabaya yang disebut arek-arek Suroboyo yakni pragmatisme, egahter, terbuka, lugas, dan kritis.

Namun demikian, tidak dapat disangkal masih adanya terjadi letupanletupan dalam skala kecil yang diindikasikan oleh adanya keluhan dan protes sebatas wacana terhadap adanya kebijakan operasional pelaksanaan misi keagamaan. Misalnya keluhan terhadap pembangunan rumah ibadah yang dianggap tidak proporsional, pengalihan fungsi bangunan tertentu menjadi "tempat ibadah" oleh pihak pemeluk agama tertentu, hal itu dipandang sebagai upaya pemenuhan kebutuhan pelaksanaan ibadah, sementara pihak pemeluk agama lain yang berada di sekitar menganggap hal itu sebagai pelanggaran terhadap "aturan main yang ada". Jadi terdapat perbedaan persepsi terhadap aturan main yang ada. Hal itulah antara lain yang dipandang sebagai faktor penghambat atau pengganggu terpeliharanya kerukunan antar umat beragama setempat.

Hal lain yang dapat dipandang faktor penghambat ialah adanya pemeluk agama tertentu melakukan kegiatan yang disifatkan sebagai "bakti sosial" kepada kelompok masyarakat hetrogen agama dengan menggunakan simbol-simbol agama tertentu. Oleh pihak pelaksana, kegiatan itu dipandang 
sebagai bagian dari pengamalan ajaran agama yakni pengamalan di bidang sosial, sementara pihak pemeluk agama lain menganggapnya sebagai bagian dari upaya "mempengaruhi" umat beragama lain. Jadi terdapat perbedaan pemahaman terhadap pengembangan misi keagamaan.

Sementera itu, dari pihak pejabat pemerintah terkait ada keluhan bahwa dalam penanganan kasus-kasus konflik bernuansa agama terkadang mereka diperhadapkan dengan situasi dilematis. Sebagai pejabat mereka dituntut melakukan upaya penanganan sebaik-baiknya tanpa memihak. Namun apabila solusi yang dicapai dianggap "tidak add" atau "tidak sesuai" menurut pemeluk agama tertentu yang kebetulan berbeda agama dengan pejabat yang menangani maka terkadang muncul tudingan bahwa sang pejabat "tidak add" atau "memihak". Menghadapi persoalan seperti itu terkadang ada oknuin pejabat yang sulit atau tidak mampu menjaga keseimbangan antara fakta dengan tuntutan misi agama yang dipeluknya. Hal ini bagi oknum pejabat yang tidak/kurang arif merupakan hambatan tersendiri dalam upaya pemeliharaan kerukunan umat beragama yang menjadi tanggung jawabnya.

\section{KESIMPULAN}

\section{A. Kesimpulan}

Ketika konflik sosial bernuansa agama bermunculan di berbagai daerah pasca orde baru, tampaknya penduduk Kota Surabaya pada umumnya tetap tenang-tenang saja melakukan aktivitas keseharian mereka, baik dalam kegiatan keagamaan secara intern maupun dalam kegiatan interaksi sosial antar umat beragama. Setidaknya ada dua hal yang mendukung terciptanya kondisi tersebut, yakni: (1) tingkat kesadaran yang tinggi dari para pemimpin dan pemuka/tokoh agama dan masyarakat setempat tentang pentingnya menjaga dan memelihara kerukunan umat beragama yang juga berarti kerukunan masyarakat; (2) ciri dan sifat khas orang Surabaya (arek-arek Suroboyo) yakni pragmatis, egaliter, terbuka, lugas, dan kritis.

Hal yang tersebut pertama di atas, ditunjukkan oleh lahir dan berfungsinya berbagai forum komunikasi umat beragama tingkat lokal Surabaya yang tumbuh dari bawah, di samping wadah sejenis bentuk pemerintah. Hal yang tersebut kedua, ditunjukkan oleh kenyataan tidak pemah terjadi konflik terbuka antar umat beragama, kecuali letupan-letupan kecil yang kemudian dengan segera dapat diterdam. 
Suasana kerukunan intern umat Islam di Kota Surabaya dan di daerah Jawa Timur pada umumnya, terkadang memunculkan suhu yang cukup tinggi, bahkan ketegangan intern umat Islam itu sendiri sebagai akibat dari penerapan euforia kebebasan dalam pengembangan pemahaman keagamaan. Solusi penanganan kasus secara hukum dan ates pertimbangan "keamanan" yang lebih bersifat "top down" semata, tampaknya kurang menuntaskan penyelesaian masalah serta masih menyisakan "sesuatu" laksana "api dalam sekam".

\section{B. Saran/Rekomendasi}

1. Sekalipun umat beragama di Kota Surabaya selama ini tidak pernah mengalami konflik terbuka bernuansa agama, namun demikian mengingat posisi Surabaya selaku kota metropolitan kedua terbesar di Indonesia yang menjadi titik pertemuan orang dari kawasan regional, nasional, dan global dengan berbagai macam kompleksitasnya maka pembinaan kerukunan umat beragama perlu ditingkatkan dan digalakkan terus oleh semua pihak yang terkait. Baik oleh pemerintah daerah dan instansi Departemen Agama setempat maupun oleh pemimpin/pemuka/ tokoh agama dan masyarakat, tidak hanya sebatas dialog dan musyawarah tetapi juga melakukan aksi sosial di tingkat grass root dengan penerapan kebijakan "pengembangan wawasan multikultural" dan pendekatan yang lebih bersifat "bottom up".

2. Sosialisasi berbagai peraturan resmi yang menjadi acuan tata hubungan umat beragama, baik yang bersifat nasional maupun lokal/daerah, dalam rangka kehidupan bermasyarakat dan berbangsa selama ini tampaknya masih perlu ditingkatkan dan digalakkan oleh pihak-pihak terkait mengingat masih adanya persepsi yang berbeda di kalangan umat beragama dalam memahami dan menerapkan peraturan tersebut (terutama isi Keputusan Bersama Menteri Dalam Negeri dan Menteri Agama Nomor 01 Tahun 1969). Atau dengan melakukan penyempurnaan/perbaikan terhadap peraturan yang telah ada.

3. Kasus-kasus yang lebih bersifat pengembangan pemahaman umat beragama secara intern terhadap ajaran agamanya, perlu disikapi lebih arif antara lain dengan mendahulukan pendekatan dialog, bahkan kalau perlu melakukan debat dengan mendatangkan pemimpin/pemuka/ahli agama bersangkutan sehingga pada akhirnya yang bersangkutan dapat menyadari dan mengakui kesalahannya. 
4. Salah satu aspek kegiatan yang masih jarang tersentuh dalam konteks penerapan kebijakan wawasan multikultural ialah aktivitas bersama di bidang seni budaya seperti pergelaran dan/atau festival seni budaya bernafaskan agama, perlombaan mengarang dan pidato bernuansa kerukunan umat beragama, anjangsana bersama ke obyek-obyek bernuansa keagamaan, dan lain-lain. Pelaksanaan aktivitas di bidang seni dan budaya tersebut perlu segera dikondisikan dan digalakkan.

\section{DAFTARPUSTAKA}

GAPURA, "Surabaya Tidak Melupakan Sejarah" (Laporan Khusus), Edisi Spesial HUT ke-712 Surabaya.

GAPURA, "Ttie Song of Soerabaia " (Laporan Khusus),, Edisi Spesial HUT ke-712 Surabaya, 2005.

Renstra (Rencana Strategik Tahun 2003 - 2005) Dinas Sosial dan Pemberdayaan Perempuan Kota Surabaya, Tahun 2003.

Soemardjan, Selo dan Soelaeman Soemardi, Setangkai Bunga Sosiologi (Jakarta: Yayasan Badan Penerbit Fakultas Ekonomi Universitas Indonesia), 1974

Sudjangi, "Pluralitas Sosial, Hubungan Antar Kelompok Agama dan Kerukunan ", dalam Harmoni, II Nomor 5 Januari - Maret 2003.

Sya'roni, Ahmad, Kepala Kantor Departemen Agama Kota Surabaya, "Profil Kantor Departemen Agama Kota Surabaya". Makalah yang disampaikan pada Studi Lapangan PUSROH LANTAMAL in AL Surabaya, tanggal 1 Juni 2004. 